\title{
JUURNAL_RU
}

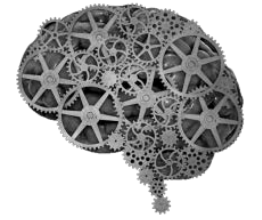

COMPANY GROUP "INTELLEKT"

Вонаршенко А.П., Борейчук А.Ф., Засядько К.И., Язлюк М.Н.
Липечкий Государственный педагогический университет Липеик, Россия

doi: 10.18411//j2016-9-2-03

idsp 000001: lj2016-18-2-03

\section{Психофизиологическое обоснование повышения надежности и работоспособности оператора управления воздушным движением с помощыю системы подготовки принятия решения}

Деятельность оператора (диспетчера) управления воздушным движением (УВД) является сложной совмещенной и сопровождается, как правило, высоким уровнем нервно-эмоционального напряжения, связанного с высокой «ценой» ошибки в его деятельности [1].

Ошибки оператора чаще всего проявляется при исчерпании психофизиологических возможностей человека в процессе принятия решений или выполнения действий в конкретной полетной ситуации [4], которая требует быстрого качественно-количественного анализа значительно объёма информации, часто в условиях, как дефицита времени, так и неточной информации [3]. Основным путем оптимизации и повышения надежности работы оператора следует считать не количественное увеличение предъявляемых ему данных, а качественное совершенствование информационного обеспечения принятия решений [5].

Это обстоятельство стимулировало разработку информационноаналитической самоорганизующейся системы поддержки (подготовки) принятия решений (СППР), как дополнение к программному обеспечению комплекса средств автоматизации (КСА) для оператора УВД. Основной функционирования СППР явилась оптимизация собственно принятие решения, которая заключалось в автоматизации процесса выбора заранее заданного алгоритма команд на управление воздушным судном. 
Целью исследования явилось проверка эффективности использования дополнения к программному обеспечению УВД в аспекте СППР. Были проведены экспериментальные исследования, организация которых предусматривала выполнение оператором своих профессиональных задач УВД в обычном штатном режиме как без использования СППР (1 серия), так и с её использованием (2 серия).

Динамика психоэмоционального состояния операторов УВД на протяжении смены оценивалась по показателям субъективной самооценки самочувствия, активности и настроения (СAH) и шкалы "Утомление, возбуждение-сонливость" (до, через каждые 30 мин. и после эксперимента).

Функционального состояние операторов УВД изучалось методом оценки вариабельности сердечного ритма. Производилось мониторирование ЭКГ с помощью последующим автоматизированным анализом значений показателя индексов напряжения физиологических систем (Баевского) [2].

Показателем надежности деятельности диспетчера УВД служило время обнаружения вводимых инструктором нештатных отклонений воздушных судов, находящихся под его контролем от заданного курса.

В исследованиях установлено, что использование СППР сопровождается оптимизацией субъективного самочувствия диспетчера, снижая чувство усталости. Так, через 4 часа работы анкетирования испытуемых по методике "Утомление, возбуждение - сонливость показало, что чувство некоторой усталости возникло только у $35 \%$ операторов, по сравнению с $80 \%$ первой серии экспериментов.

Результаты анализа самооценки операторов УВД своего состояния во второй серии исследований свидетельствовали о том, что их самочувствие, активность и настроение даже несколько улучшилось к середине "рабочей смены”, достигая значений 5,6-5,8 баллов, оставаясь на довольно высоких значениях к концу смены, что достоверно выше $(\mathrm{P}<0,05)$ значений аналогичных показателей в первой серии исследований.

Использованием СППР повысило и надежность деятельности операторов УВД что выразилось в более быстром $(\mathrm{P}<0,05)$ реагировании испытуемым на отклонение вводимой метки ВС. 
Однако, напряженность функционирования систем жизнеобеспечения деятельности авиадиспетчера не претерпевала значимых изменений, на что указывали данные динамики значений показателя индекса напряжения регуляторных систем в обеих сериях экспериментов.

Результаты проведенного анкетного опроса операторов, участвующих в исследованиях, показали в целом положительную оценку эффективности применения изучаемой системы, в частности $30 \%$ опрошенных отмечали значительное улучшение деятельности, $60 \%$ - улучшение и только $10 \%$ отмечали некоторое улучшение.

Таким образом, проведенные исследования выявили, что использование СППР как дополнения к программному обеспечению КСА имеет существенные преимущества, заключающиеся в достоверно лучшей оценке субъективного состояния и более высокой надежности профессиональной деятельности диспетчера УВД, что будет способствовать оперативности и высокому качеству принимаемых решений. 


\section{Литература:}

1. Горюнова, Л.Н. Операторская деятельность в человекотехнических системах/ Л.Н. Горюнова. - СПб.: 2006 -200 С.

2. Михайлов В.М. Вариабельность ритма сердца: опыт практического применения метода.Изд. второе, перераб. и доп.: Иваново: Иван. Гос. мед. академия, 2002.- 290с.

3. Смирнов, Б.А. Основа инженерной психологии; Учебник для студентов вузов/ Б.А. Смирнов, А.И. Королев, Б.А. Душков - М.: Академический проект. Деловая книга, 2002 - С. 576.

4. Пономаренко, В.А. Теоретические и экспериментальные данные о профилактике безопасности полета/ В.А. Пономаренко - М.: КогитоЦентр, 2014 - С. 104.

5. Стрелков, Ю.К. Инженерная и профессиональная психология/ Ю.К. Стрелков - М.: 2001 - С. 205. 